\title{
Virtual Laboratory for supporting chemistry learning and practicing
}

\author{
Juan Carlos Guevara Bolaños \\ Universidad Distrital Francisco José de Caldas \\ Bogotá, Colombia \\ jcguevarab@udistrital.edu.co
}

\author{
Lely Luengas Contreras \\ Universidad Distrital Francisco José de Caldas \\ Bogotá, Colombia \\ laluengasc@udistrital.edu.co
}

\begin{abstract}
This paper describes the importance of developing learning tools, such as virtual laboratories in different areas of science with emphasis in chemistry, through the development of a virtual laboratory that allows students to access to an environment of experiential learning. It has two main stages which are: a virtual world (software) where the student is guided by an integrated environment with the features necessary in order to perform the practices and at the same time, has a capture stage (hardware) that is responsible for making the process of experimentation as real as possible, offering the instrument's sensation or machine's sensation during the experiments. Throughout the document the steps for the completion of the virtual laboratory are seen with the results so far.
\end{abstract}

Keywords-chemistry, distillation; virtual laboratory; virtual reality.

\section{INTRODUCTION}

Today the implementation of educational tools in interactive environments has allowed the acquisition of knowledge, it presents an innovative and efficient way to learn and teach giving the opportunity for students to access experimentation in an almost real manner, allowing their full learning which is not dependent on specific artifacts and materials but on accessing to the virtual laboratory.

Nowadays, there is an increasing popularity in virtual laboratory environment for its prominent advantages of intuition and interactivity between teaching and studying [1]. Interactive tools accompanied by modern educational theories configure a tool that currently has a very important impact in students of all areas of science and technology and has a main role in the current educational process.

The objective of the virtual laboratory proposed in this paper is to create a laboratory environment which motivates students to discover connections between theory, simulation, and physical systems through independent experimentation with up-to-date professional tools. [2]

The implementation of information and communication technologies has developed different types of virtual laboratories, in this case is being developed a virtual laboratory which has a virtual world that allows the immersion in an environment conducive to practical implementation of distillation in chemistry field, along with an electronic device specifically a virtual reality glove that has the function to capture the movements and position of the student's hands, and thus making the practice very close to reality and generating a theoretical and practical learning.

Although theoretical concepts are essential and need to be taught, it is very important to also show students how to apply the theory they have learnt in very different and important practical situations. [3] In some areas of knowledge the apprenticeship is not complete until you have developed different practical activities, so an example of this case is the chemistry field. Many subjects are based on it (practicing and experimenting), especially subjects which have more practicalness, such as: programming, physics, chemistry, and other engineering subjects. [4]

Besides the development of such interactive tools is necessary to promote a new culture in the learning process, since there must be a motivation with students who are interested in using tools and devices built for intellectual growth, is necessary to discard traditional pedagogy that leaves very little scope to the student and instead propose a constructivist pedagogy which guides the student to identify and define the problem, the proposal procedures, collection and interpretation of results and making decisions. [5]

Besides, virtual laboratory can also benefit distance education and learning-on-the-job students, who maybe asynchronous in time or in space, even more, for the cost and time needed for traveling to a local lab would often prevent them from using such real laboratories. Moreover, the virtual laboratory resources can be shared by many institutions and students worldwide, which can save much money. [6] There are many applications and advantages of virtual laboratories as their implementation in distance education or the acquisition and management of expensive tools and machinery that is not easily acquired.

Therefore, the main research question to be solved is: How to develop a virtual laboratory of basic distillation that can be handled from an electronic device (virtual reality's glove), to support the teaching process of distillation? From the previous question and development experience of the research group in this type of tool, the following questions arise also be solved with the investigation: How to design and develop a motion capture device that allows sense signals generated by a hand movement? And how to design and develop a three- 
dimensional interface that allows displaying the manipulation of objects in a basic distillation laboratory from a remote hand and support the teaching process distillation?

\section{VIRTUAL LABORATORIES}

\section{A. History Background}

Due to the need for student support systems to make their laboratory practices, with the aim of optimizing time and resources required in a controlled environment to provide security, the advancement of new technologies of information and communication and adoption of recent educational and pedagogical practices, emerged virtual labs as a support for the process of student learning.

The approach now in education, where new spaces are built and troubleshooting, virtual laboratories, have gone deep into the pedagogical practices, for over 25 years or so, when its use began. The first approach to virtual laboratories appears in 1984, where the concept of virtual instrument and its characteristics were determined according to the fundamentals of programming. [7]

In 1992, virtual laboratories described the object-oriented programming in the development of a laboratory simulation. In 1994 was presented a study by Vanderbilt University in the U.S. which develops a simulation-based virtual laboratory to support traditional practices, which concluded with the need for this tool to learn basic skills and equipment management, which optimizes both the time of pupils as the laboratory staff, in 1994 was written an article [8] in which is explicitly defined a virtual laboratory as a simulation program.

Already in the IMTC conference (IEEE Instrumentation and Measurement Technology Conference) held in June 1996, started to present different aspects of what is a virtual laboratory.

\section{B. Concept}

A Virtual Laboratory is an interactive virtual space that incorporates all the technological, pedagogic and human resources in order to perform practical activities, adapted to the student's and teacher's needs in a virtual learning environment [9].

The virtual laboratory is composed by a virtual world which is based on the required pedagogy by the area of science where it is implemented and the development of the virtual environment to make it comfortable and real to the student. Along with a hardware tool which is an essential resource for learning as it provides comprehensive real sense of the object that is being manipulated within the virtual laboratory.

In addition the laboratory should have the following Characterisitcs says Vikram Padman and Nasir Memon [3] Accessibility, Observability, Ability to simulate realistic scenarios, Realistic, Separability of virtual network, Remote Configurability, Ability to share resources efficiently. With accessibility it is understood that a student can easily access the virtual laboratory and its elements, the Observability characteristic is about the possibility of students to observe the effects of their actions within the virtual laboratory, as it would be in reality.

The ability to simulate realistic scenarios, where realistic, mean that the virtual laboratory should have an environment that gives a real sensation of the practice. The separability of virtual network, Remote configurability and Ability to share resources efficiently are Referred to the capability of the virtual laboratory to allow interacting with it by many students at the same time, without generating problems in the virtual environment also the virtual laboratory should permits to be modified at any time by the laboratory's administrator.

\section{Importance}

Despite distance education acquires some results in theory teaching, the expansion of the experiment manipulation teach has become the main factor which restricts the further development of distance education. [4]

The importance of virtual laboratories can be seen in distance education as these allow students to access information from different places, it is not necessary for them to be at the same school or even in the same location.

Engineering students need to practice and perform experiments in laboratories in order to complement their learning process. However, instructors and equipment are not always available. Additionally, there may be risk and trouble using some equipment that may hurt students or damage the equipment. [10]

In these cases the use of virtual labs is the best option for engineering students where is needed to use equipment that do not have or it use is dangerous for the student. Thus, it appears that some of the main reasons for using these tool: the decrease in investment in expensive machines, the expansion in the restricted access to expensive laboratory equipment and, the limited availability of free time in laboratories for new practices to enhance knowledge on a specific issue and reducing the cost of consumable items.

\section{CHEMISTRY VIRTUAL LABORATORY}

The virtual laboratory was designed and is under development to support the teaching of chemistry distillation consists of three basic components: an interaction device (suits, gloves, helmet or other component that allows movement user), a motion capture device (electronic device that receives signals (movement) of the user and transmits to the computer) and a software interface (virtual world) that contains a threedimensional scene with real-world elements simulated, which is operated with the signals received from the motion capture device. Additionally, the software interface (virtual world) incorporates in its operation a teaching model and didactic to facilitate the learning process. 
The interaction device consists of a virtual reality glove which senses movements of the student's hand capturing the different activities that can do in the distillation process in the virtual laboratory implementing low-cost sensors that make the glove more accessible to all users. The motion capture device is responsible for capturing the different signals from the virtual reality glove to identify and order it with reference to the voltage found on the analog inputs of a microcontroller and then feedback a response to the virtual world of the computer where it generates a real-time response to the action performed by the student.

The software interface (virtual world), includes the basic elements of a laboratory distillation within a scenario of three dimensions, which are handled according to data supplied by the motion capture device. The interface is being developed with software for virtual worlds building in third dimension (such as VRML, X3D and Blender), signal capture programs, programs with special procedures and intelligent agents (developed in Java programming language), enabling to provide an interactive environment for users. Additionally, the interface has a constructivist approach and a learning component based on the resolution of problems, some examples are showed in table 1 .

\section{TABLE I. EXAMPLES OF SOME VIRTUAL LABORATORIES}

\begin{tabular}{|l|l|}
\hline \multicolumn{1}{|c|}{ Virtual Laboratory's name } & \multicolumn{1}{|c|}{ Authors } \\
\hline $\begin{array}{l}\text { Vital (virtual } \\
\text { Information assurance laboratory) }\end{array}$ & $\begin{array}{l}\text { Vikram Padman and Nasir } \\
\text { Memon [3] }\end{array}$ \\
\hline $\begin{array}{l}\text { Virtual laboratory for signals } \\
\text { And systems }\end{array}$ & Virginia L. Stonick [2] \\
\hline $\begin{array}{l}\text { Simulated lathe virtual laboratory } \\
\text { (LaSiTo) }\end{array}$ & $\begin{array}{l}\text { Julieta Noguez, Gilberto } \\
\text { Huesca [10] }\end{array}$ \\
\hline $\begin{array}{l}\text { UVL (universal virtual laboratory) } \\
\text { Michael Duarte, Brian P. Butz } \\
\text { Susan M. Miller, and }\end{array}$ \\
$\begin{array}{l}\text { Annapoorna Mahalingam [19] } \\
\text { (virtual networking }\end{array}$ & $\begin{array}{l}\text { Josep Prieto-Blázquez, Joan } \\
\text { Arnedo-Moreno, and Jordi } \\
\text { Herrera-Joancomartí [9] }\end{array}$ \\
\hline $\begin{array}{l}\text { Virtual Laboratory } \\
\text { laboratory ) }\end{array}$ & $\begin{array}{l}\text { Lucian Rodrigues de Queiroz, } \\
\text { Marcel Bergerman, Rubens } \\
\text { Campos Machado, } \\
\text { Samuel Siqueira Bueno, Albert }\end{array}$ \\
\hline
\end{tabular}

\section{METHODOLOGY}

The development of the project involves a combination of several methodologies: one for the development of the research process Table 2, one for an interaction device (virtual reality glove) Table 3, another to do the motion capture device Table 4 , one for the design and development of a software interface that reflects a virtual world of a basic distillation laboratory supported in the teaching model of problem solving Table 5.

Initially defined and explained in Table 2, the research process that will be followed from the research process models proposed by Morgan silver [11], Lerma [12], Tamayo [13] and Cerda [14].

TABLE II. RESEARCH METHODOLOGY

\begin{tabular}{|l|l|}
\hline \multicolumn{1}{|c|}{ Stages } & \multicolumn{1}{|c|}{ Description } \\
\hline Defining the topic & $\begin{array}{l}\text { During this stage, it was clearly defined and } \\
\text { precisely the work area or field of research } \\
\text { problem. }\end{array}$ \\
\hline $\begin{array}{l}\text { Indentifying the } \\
\text { problem }\end{array}$ & $\begin{array}{l}\text { During this stage, it was specified in detail and } \\
\text { precisely the problem. Defining the limits of the } \\
\text { research. }\end{array}$ \\
\hline $\begin{array}{l}\text { Defining } \\
\text { Objectives }\end{array}$ & $\begin{array}{l}\text { During this stage, the objectives were defined } \\
\text { taking into account the actual results, scope and } \\
\text { results. }\end{array}$ \\
\hline $\begin{array}{l}\text { Definition } \\
\text { Justification }\end{array}$ & $\begin{array}{l}\text { During this stage, it was defined the motivations } \\
\text { that led to the development of the project. }\end{array}$ \\
\hline framework & $\begin{array}{l}\text { During this stage, we took into account the } \\
\text { previously constructed knowledge, which is part of } \\
\text { the existing theoretical structure and experiences in } \\
\text { the world. }\end{array}$ \\
\hline $\begin{array}{l}\text { Definition of the } \\
\text { methodology }\end{array}$ & $\begin{array}{l}\text { The investigation was developed in three phases, } \\
\text { the first consist of the construction of interaction } \\
\text { device (Virtual Reality glove). In the second phase, } \\
\text { was built the motion capture device. In the third } \\
\text { phase, there was the software interface that contains } \\
\text { the virtual world of basic laboratory distillation. }\end{array}$ \\
\hline
\end{tabular}

The development of interaction device (Virtual Reality glove) was done following the steps described in Table 3.

TABLE III. INTERACTION DEVICE METHODOLOGY

\begin{tabular}{|l|l|}
\hline \multicolumn{1}{|c|}{ Stages } & \multicolumn{1}{c|}{ Description } \\
\hline $\begin{array}{l}\text { Planning and } \\
\text { organization }\end{array}$ & $\begin{array}{l}\text { At this stage is defined what will be done, the list of } \\
\text { activities, team work, artefacts that constitute the } \\
\text { device and the required tools. }\end{array}$ \\
\hline Requirements & $\begin{array}{l}\text { At this stage is setting out the different characteristics } \\
\text { that the device must have }\end{array}$ \\
\hline Analysis & $\begin{array}{l}\text { At this stage, is analyzed the requirements set at the } \\
\text { previous stage and build a model to define which are } \\
\text { the components of the device and how they operate, } \\
\text { determining the physical structure and technology } \\
\text { used. }\end{array}$ \\
\hline Devices design & $\begin{array}{l}\text { At this stage, are made the sketches, proposals for } \\
\text { structural design and performance, overall design of } \\
\text { the glove, transducers design }\end{array}$ \\
\hline $\begin{array}{l}\text { Development and } \\
\text { construction }\end{array}$ & $\begin{array}{l}\text { At this stage, is made the glove implementation, the } \\
\text { sensors, signal conditioning and signal transmission }\end{array}$ \\
\hline Tests & $\begin{array}{l}\text { At this stage, individual tests are performed and } \\
\text { capture device. }\end{array}$ \\
\hline
\end{tabular}

The motion capture device is done following the steps defined in Table 4. 
TABLE IV. CAPTURE DEVICE METHODOLOGY

\begin{tabular}{|l|l|}
\hline \multicolumn{1}{|c|}{ Stages } & \multicolumn{1}{c|}{ Description } \\
\hline Requirements & $\begin{array}{l}\text { At this stage is defined the requirements of motion } \\
\text { capture device taking seeing the requirements and } \\
\text { system software in general. }\end{array}$ \\
\hline Analysis & $\begin{array}{l}\text { Taking into account the requirements, the devices are } \\
\text { designed as well as their characteristics }\end{array}$ \\
\hline Design & Design and simulation of the capture system. \\
\hline Implementation & Performing the installation of the device. \\
\hline Tests & Adaptation and testing of signal acquisition \\
\hline
\end{tabular}

The methodology for the design and development of the software interface that contains the virtual world of a basic distillation laboratory will follow the RUP methodology from the models Jacobson, I., Booch, G. and Rumbaugh [15], Weitzenfeld [16] Scharch [17] and [18].

TABLE V. VIRTUAL WORLD METHODOLOGY

\begin{tabular}{|l|l|}
\hline \multicolumn{1}{|c|}{ Stages } & \multicolumn{1}{c|}{ Description } \\
\hline Business & $\begin{array}{l}\text { At this stage is identified the main processes that will } \\
\text { be performed in the laboratory, will make the process } \\
\text { diagrams, domain model and a glossary of terms. }\end{array}$ \\
\hline Requirements & $\begin{array}{l}\text { At this stage is defined the virtual laboratory } \\
\text { requirements for which were made the initial list of } \\
\text { use cases, the clearance of these, their model and } \\
\text { documentation of each use case. }\end{array}$ \\
\hline Analysis & $\begin{array}{l}\text { At this stage is defined the conceptual view of the } \\
\text { virtual laboratory, for which it was done, sequence } \\
\text { diagrams, collaboration and activity for each use case, } \\
\text { the state diagram and model analysis. }\end{array}$ \\
\hline Design & $\begin{array}{l}\text { At this stage is defined the programming vision of the } \\
\text { virtual laboratory for which shall be carried out CRC } \\
\text { tables to establish the responsibilities of the objects, } \\
\text { the interface model, the logical model, physical model } \\
\text { and data dictionary. }\end{array}$ \\
\hline Implementation & $\begin{array}{l}\text { At this stage the schedule is made of the various } \\
\text { systems that comprise the virtual laboratory, which } \\
\text { will be made for the deployment diagrams, packages } \\
\text { and components and the code of each of the } \\
\text { subsystems. }\end{array}$ \\
\hline Tests & $\begin{array}{l}\text { At this stage the tests are conducted and system } \\
\text { integration of each of the systems comprising the } \\
\text { virtual laboratory }\end{array}$ \\
\hline
\end{tabular}

\section{RESULTS}

The developments achieved in the project, offer opportunities to acquire knowledge for the deployment of new virtual labs, creating virtual worlds, design and development of motion capture devices based on wireless sensors and cameras, as well deploying applications as telepresence, which can be used generically to build solutions in education, health, entertainment, industrial, etc.

The project helped to identify mechanisms to incorporate the teaching model of problem solving within the operation of the virtual world, which has facilitated the use by students of the device.

The construction of the laboratory includes the formation of a task force comprised of people from different professions (system engineers, electrical engineers, designers, educators, teachers and students of the subject of chemistry), who have worked in an organized and have allowed the approach new projects, seen from different perspectives.

\section{DISCUSSION}

The design and development of virtual laboratories oriented to education should consider incorporating educational and teaching models, because it facilitates the use and student motivation to perform the various practices in the laboratory.

The practices that students will perform in the virtual laboratory, must be integrated with the programming being done by the class teacher, as this allows better results in the transfer of the different concepts.

The development team of a virtual laboratory oriented to education must have professionals from different areas such as systems engineers, electrical engineers, designers, educators and experts in the field that allows the construction of the laboratory from different perspectives.

\section{REFERENCES}

[1] Zhu Yonghua, Pan shunhong, Dong Zhiling and Yao Hong, "An Interactive and Expansible Virtual Laboratory Environment for Hardware Chips Application Experiment". Proceedings of the First International Workshop on Education Technology and Computer Science, 2009.

[2] Virginia L. Stonick, "An update on the cmu virtual laboratory". Electrical and Computer Engineering Department. Carnegie Mellon University, Pittsburgh, PA. 1994.

[3] Vikram Padman, Nasir Memon, "Design of A Virtual Laboratory for Information Assurance Education and Research". In Proceedings of the 2002 IEEE Workshop on Information Assurance and United States Military Academy 2002.

[4] Zhao Ya, Liu Xianmei and Wu Qiong, "The Research and Implementation of Virtual Laboratory based on Web in Distance Education". In Proceedings of the 4th International Conference on Computer Science \& Education 2009.

[5] Mora, William, Garcia, Alvaro, "La resolución de problemas: una línea prioritaria de investigación en la enseñanza de las ciencias", In línea de investigación en docencia de la química, Proyecto Curricular de Licenciatura en Química. Universidad Distrital Francisco José de Caldas. 2008, P. 15-17.

[6] Gu Rong, Zhu Miaoliang, Dong Yabo, Shi Dandan and Wang Yonggu, "A Case Study of Virtual Circuit Laboratory for Undergraduate Student Courses", In ITHET 6th Annual International Conference. Juan Dolio, Dominican Republic 2005.

[7] Rodrigo, V., and Ferrando, Miguel., "Virtual Instrumentation: First step towards a virtual laboratory", In IEEE International workshop on virtual and intelligent measurement systems. Annapolis, Maryland, 2000.

[8] Goldberg, K,. "The Mercury project - Robotic tele-excavation. Beyond the Web: Excavating the Real World Via Mosaic". In The International WWW Conference. Chicago, 1994.

[9] Prieto-Blazquez, J.; Garcia-Tora, I.; Herrera-Joancomarti, J.; GuerreroRoldan, A.-E., "Virtual Laboratory ontology for engineering education," Frontiers in Education Conference, 2008. FIE 2008. 38th Annual, vol., no., pp.S2F-1-S2F-6, 22-25 Oct. 2008.

[10] Noguez, J.; Huesca, G., "LaSiTo: A lathe simulated virtual laboratory," Frontiers in Education Conference, 2008. FIE 2008. 38th Annual, vol., no., pp.S2A-13-S2A-18, 22-25 Oct. 2008 
[11] Méndez, C. "Metodología. Diseño y desarrollo del proceso de investigación". Tercera Edición. Colombia: Editorial Mc Graw Hill, 2001.

[12] Lerma, H. "Metodología de la investigación: Propuesta, Anteproyecto y Proyecto”. Segunda Edición. Bogotá: Ecoe Ediciones. 2005.

[13] Tamayo, M. "El proceso de la investigación científica". Cuarta Edición. México D.F.: Editorial Limusa, 2005.

[14] Cerda, H. "Los elementos de la investigación”. Segunda reimpresión. Bogotá: Editorial El Búho, 2000.

[15] Jacobson, I., Booch, G. and Rumbaugh, J., "El Proceso Unificado de Desarrollo de Software". Primera edición. España:Editorial Addison Wesley. 2001

[16] Weitzenfeld, A. "Ingeniería de Software Orientada a Objetos con UML, Java e Internet”. México: Ed. Thomson, 2005.

[17] Scharch, S. "Ingeniería de Software Clásica y Orientada a Objetos". Sexta edición. México: Ed. Mc Graw Hill, 2006.
[18] Scharch, S., "Análisis y Diseño Orientado a Objetos con UML y el Proceso Unificado”. México: Ed. Mc Graw Hill, 2005.

[19] Duarte, M.; Butz, B.P.; Miller, S.M.; Mahalingam, A., "An Intelligent Universal Virtual Laboratory (UVL)," Education, IEEE Transactions on , vol.51, no.1, pp.2-9, Feb. 2008.

[20] De Queiroz, L.R.; Bergerman, M.; Machado, R.C.; Bueno, S.S.; Elfes, A., "A robotics and computer vision virtual laboratory," Advanced Motion Control, 1998. AMC '98-Coimbra., 1998 5th International Workshop on , vol., no., pp.694-699, 29 Jun-1 Jul 1998 URL: http://ieeexplore.ieee.org/stamp/stamp.jsp?arnumber=743639\&isn umber $=15921$ 
